\title{
2 径間高塔型エクストラドーズド橋の構造特性
}

\author{
川崎 秀明 ${ }^{1} \cdot$ 松下博通 $^{2}$ \\ ${ }^{1}$ 正会員 工修 沖縄開発庁 北部夕゙ム事務所長（广905-8501 沖縄県名護市字名護 4752） \\ ${ }^{2}$ 正会員 工博 九州大学教授 大学院工学研究科 (广810-8531 福岡市東区箱崎 6-10-1)
}

\begin{abstract}
PCエクストラドーズド橋は，PC斜張橋と PC箱析橋の中間領域の支間長に適する橋梁形式として近年実施例が增え ているが, 従来の同形式は 3径間以上であり主塔の高さも 10 15m と低く抑えられている.これに対し 2 径間の場合, 両端支持であるため元々応力変動や変位に対して強く,その分主塔高を高くすることによって主析の応力状態を大きく 改善し, 主析・斜材の部材量を低隇することが可能と考えられる.そこで, 主塔・主桁・斜材の主要 3 部材の特性と限 界を分析し構造系全体の最適化を進め, 結果として従来PCエクストラドーズド橋の倍程度 (斜張橋の半分程度) か経 済的に最も有利であり, 応力上も問題ないことが判った. この成果は設計と施工によって確認したが, 本研究はその経 験も踏まえてより最適な橋梁構造を提案するものである.
\end{abstract}

Key Wonds : PC exradosed bridge, PC cable stayed bridge, two span \& higher tower, optimal structural design

\section{1.はじめに}

PCエクストラドーズド橋（以下，エクストラドーズド 橋) は, 主塔からの斜材ケーブルによって床版を吊る PC 斜張橋（以下, 斜張橋）と主林の剛性によって構造系を 保つ桁橋の双方の特徵を併せ持つ構造形式であり，中央 支間 100〜200mクラスでの優れた最新橋梁タイブとし て近年実施例が増えているが，従来の主塔の高さは支間 長の $1 / 10 〜 1 / 12$ 程度と低く抑えられている. なお, 主塔 高に関する既往研究は多径間対象ではあるが ${ }^{122}$, 斜材応 力変動幅, 鉛直荷重負担率, 曲げモーメント低減効果等 の点から, 支間長の $1 / 8 \sim 1 / 12$ を適当としている.

しかし, 両端が支点支持される 2 径間においては, 斜 材の応力変動幅に余裕があるため, さらに主塔を高くし て中間支点での曲げモーメントを滅らすことで一層経済 的な構造設計が可能であると考え, 研究を進めた.

この 2 径間高塔型の理論を既往最大級の張出し長 $110 \mathrm{~m}$ のまたきな大橋設計に適用して従来の倍程度の主 塔高か経済的に最適であるとの結論を得た. その後, 実 施工および計測によって当構造の妥当性を確認した.

本稿は,これら設計〜施工を通じて得られた結果をも とに, 主塔・主桁・斜材の構造特性と経済性への影響を 分析し，2 径間高塔型の有利性について総合的に評価し たもので，実構造を検証しスパン長大化を検討した。

今回の 2 径間高塔型提案は, 従来のエクストラドーズ ド橋と斜張橋の中間領域に今までに無い優れた橋梁構造 が存在し将来可能性に富むことを示しているが，今後の $\mathrm{PC}$ 橋梁設計の最適化に寄与できれば幸いである.

\section{2径間高塔型エクストラドースド橋の目的}

\section{（1）主要部材から見た力学的目的}

\section{a) 斜材}

従来エクストラドーズド橋の斜材は，主塔による大偏 心モ一メントを主桁に与え柱頭部の負モ一メントの軽減 によって効果的なプレストレスを与えることを主要目的 としている. また, 斜張橋の斜材は吊材機能により主枌 の鉛直荷重負担を極力抑えることを目的としている.

一方，2 径間高塔型エクストラドーズド橋の斜材は， より高い主塔を利用した大偏心モーメントによって柱頭 部負のモーメントをさらに軽減することを主な目的とし ているが, 斜材の吊材効果に伴う自重軽隇による柱頭部 負のモ一メントの軽減も付加される. なお, 負のモ一メ ントを抑えることは，設計上最もクリティカルとなる主 桁柱頭部の応力を軽減するという意味を持つ.

b) 主桁

エクストラドーズド橋は, 斜張橋よりも主桁高増によ り片持ち梁の張出し区間を長くすることで, 斜材の架設 区間および斜材工費用を減じている. 一方, 斜張橋の主 桁は全長にわたって斜材に吊られるために，打設ブロッ ク分の張出しに耐える主桁高を確保すればよい.

エクストラドーズド橋を斜張橋から外钼的に明確に区 別する特徵として,「主桁高が大きい,斜材が全長にわた って張られていない，大半は柱頭部で主析高増がある」 等があり,この点, 主桁高を斜張橋の倍近くまで高くす る等の上記特徵を有する今回の 2 径間高塔型構造は, 基 本的にエクストラドーズド橋であると考えられる. 
表一1 桁高変化による柱頭部曲げモ一メント值 $(\mathrm{kN} \cdot \mathrm{m})$ （径間長 $110 \mathrm{~m}$ ，主塔高 $26.3 \mathrm{~m}$, 斜材 15 段, B活荷重)

\begin{tabular}{|c|c|c|c|}
\hline 桁高： 柱頭部〜標準部 & $6-3 m$ & $6 \sim 3.5 \mathrm{~m}$ & $6-4 m$ \\
\hline $\begin{aligned} \text { 自重モーメント } \\
\text { モーメント比 }\end{aligned}$ & $\begin{array}{r}-489,958 \\
1.00 \\
\end{array}$ & $\begin{array}{r}-583,747 \\
1.19 \\
\end{array}$ & $\begin{array}{r}-669,192 \\
1.37 \\
\end{array}$ \\
\hline 桁内 PC鋼材モーメント & 83,698 & 85,588 & 87,888 \\
\hline $\begin{array}{r}\text { 斜材張力モーメント } \\
\text { モーメント比 }\end{array}$ & $\begin{array}{r}582,231 \\
1.00 \\
\end{array}$ & $\begin{array}{r}664,875 \\
1.14 \\
\end{array}$ & $\begin{array}{r}734,859 \\
1.26 \\
\end{array}$ \\
\hline 設計荷重時 & 32,738 & 28,945 & 18,110 \\
\hline クリーフ乾燥収縮後 最小 & $-6,682$ & $-14,210$ & $-21,676$ \\
\hline 斜材応力変動幅 $\Delta \sigma \mathrm{N} / \mathrm{mm}^{2}$ & 29.9 & 24.8 & 21.1 \\
\hline
\end{tabular}

\section{c) 主塔}

主塔は上記の斜材と主桁の機能発揮のために必要な高 さを持てばよい。ちなみに, Mathivat（エクストラドー ズド橋提案者）の $\mathrm{H} / \mathrm{L}$ (主塔高/支間長) は $1 / 15$ である が，害績主塔高は支間長の 1/10～1/13 が多い.これに対 し斜張橋の実績 $\mathrm{H} / \mathrm{L}$ は $1 / 4$ 前後が多い. 2 径間高塔型の 最適主塔高は両者の中間に位置すると考えられる.

\section{(2) 本研究の目的}

2 径間高塔型エクストラドーズド橋を構成する主塔, 主桁, 斜材の力学的特性を把握し, 各部材の影響度合い を分析することで，構造系全体の経済性追求による設計 の最適化を図る.さうら，実施工へ適用して力学的安全 性, 施工性向上, 経済性の検証を行い, 長径間化の可能 性を探ることで, 将来の橋梁構造の発展に資する.

なお，検討モデルは䬿往最大の張出し長 $110 \mathrm{~m}$ を持つ 2 径間橋梁である「またきな大橋」とした. (図一9)

\section{3. 部材別構造分析}

主塔, 主桁, 斜材の主要 3 部材について径間長 $110 \mathrm{~m}$ $\times 2$ 径間の等径間モデルによるパラメー夕解析を行い, 各部材特性の構造全体に与える影響について分析した。

\section{（1）主杕高（標染部の主林高）}

主桁高を増した場合, 主桁岡性増により斜材の荷重負 担率が減る一方で，主桁の自重増により曲げモーメント が増えるためその経済性は微妙で確認の必要がある.

主塔高 $26.3 \mathrm{~m}$ の条件で主桁高（柱頭部〜標準部）を 6 3m から 6 4m に高くした場合, 自重增による負モーメ ントの増が大きいために, 斜材張力と桁内 $\mathrm{PC}$ 鋼材プレ ストレスの必要量はむしろ增える. ただし，自重の負の モ一メント増 37\%に対して斜材張力増は 26\%であり, 主 桁の鉛直荷重分担は確実に進んでいる.（表一1）

以上より「主桁を高くすると斜材の鉛直荷重分担の比 率は下がるが,斜材張力の軽减効果は余り期待できない」 と言える.さらに, 主桁自重增により下部工への負担が 大きくなるため主桁高增はさらに不利になる.
表一2 主塔高変化による柱頭部曲げモーメント值 $(\mathrm{kN} \cdot \mathrm{m})$

（主塔高変化と主桁高 6 3.5m 設定の以外は表一1 と同一条件）

\begin{tabular}{|c|c|c|c|c|c|}
\hline \multicolumn{2}{|c|}{ 主塔高 } & $20.8 \mathrm{~m}$ & $26.3 \mathrm{~m}$ & $30.2 \mathrm{~m}$ & $35.5 \mathrm{~m}$ \\
\hline \multicolumn{2}{|c|}{ 自重モーメント } & $\begin{array}{r}-746,217 \\
1.00 \\
\end{array}$ & $\begin{array}{r}3,153 \\
0.78 \\
\end{array}$ & \begin{tabular}{r|}
$-509,618$ \\
0.68 \\
\end{tabular} & $\begin{array}{r}436,538 \\
0.59 \\
\end{array}$ \\
\hline \multicolumn{2}{|c|}{ 桁内 PC鋼材 II } & 88 & 8 & & 83,8 \\
\hline \multicolumn{2}{|c|}{ 斜材張力” } & $\begin{array}{r}766,952 \\
1.00 \\
\end{array}$ & $\begin{array}{r}664,197 \\
0.87 \\
\end{array}$ & $\begin{array}{r}\mathbf{6 2 5}, 639 \\
0.82 \\
\end{array}$ & $\begin{array}{r}\mathbf{5 8 2 , 3 3 8} \\
0.76 \\
\end{array}$ \\
\hline \multirow{2}{*}{$\begin{array}{c}\text { 設詰十荷重 } \\
\text { 時 II }\end{array}$} & 最大 & $-3,679$ & 25,387 & 41,382 & 54,858 \\
\hline & 最小 & $-48,149$ & $-14,196$ & 4,488 & 20,237 \\
\hline \multicolumn{2}{|c|}{ 斜材応力変動幅 $\mathrm{N} / \mathrm{m}$} & 20. & 27.6 & 36.9 & 47.4 \\
\hline
\end{tabular}

\section{（2）主塔高（橋面から主塔の先端までの高さ）}

主塔高を $20.8,26.3,30.2,35.5 \mathrm{~m}$ (側径間長 $110 \mathrm{~m}$ 比 で各々 $1 / 5,1 / 4,1 / 3.5,1 / 3)$ と高くした場合, 表一2の ように柱頭部では，自重による負のモーメントが大きく 減り，それに対応して必要な斜材張力は大きく減り，桁 内 PC 鋼材量も僅かに減る.また，曲げモーメントも大 きく軽減され, 主桁内の発生応力は大幅に改善される.

当章では主塔高増の効用を斜材張力滅による斜材容量

（径）の減に用いたが，桁内 $\mathrm{PC}$ 鋼材の減 (4章参照)， 主桁高の減, 長径間化（6章参照）にも有効である.

\section{（3）斜材}

斜材は主桁内のコンクリート応力が許容值内に収まる ように配置され，PC 鋼材許容值内の張力が与えられる. 斜材の設定は，架設区間，段数，太さ等の選定要素が 多く複雑だが，下記に従って分析を進めた.

\section{a) 斜材と桁内 PC 鋼材量の配分}

斜材は桁内 PC 鋼材（ケーブル or 鋼棒）より高価だが 大偏心であるため, より少ない鋼材量で柱頭部発生応力 軽滅に有利な正のモ一メントを与えることができる.

そこで，当モデルでは効率の良い斜材を優先配置し， 桁内 $\mathrm{PC}$ 鋼材を必要最小限の量にとどめることで, 総 PC 鋼材量をできるだけ抑制し，その結果，斜材段数は 15 段と多めとなった. 一方, 従来エクストラドーズド橋で は，桁内 PC 鋼材を多く併用するのが一般的で，斜材優 先配置とは異なる.これら 2 手法の経済上の優劣は一概 には言えず，斜材と析内 PC 鋼材の価格差と配分量, 斜 材張力の余り具合等で変わるものと考えられる.

\section{b) 主桁高と斜材架投区間}

エクストラドーズド橋では基本的に図ー1のように， 柱頭部からのTラーメン張出し部（柱頭部〜最下段斜材 架設位置) と最上段斜材位置からの先端張出し部（最上 段斜材架設位置〜先端）の片持ち梁としての両張出し区 間を先に決め,残りを斜材架設区間として設定している. よって, 主桁高か增せば主桁の片持ち梁施工が可能な区 間が增え斜材架設区間が減るはずだが, 表一1 のように 主塔高が高い場合は，自重増が主桁内断面力増に鋭敏に 影響するため，主桁高を増やしても斜材の荷重負担も増 え架設区間の滅に結びつかない結果となつた. 


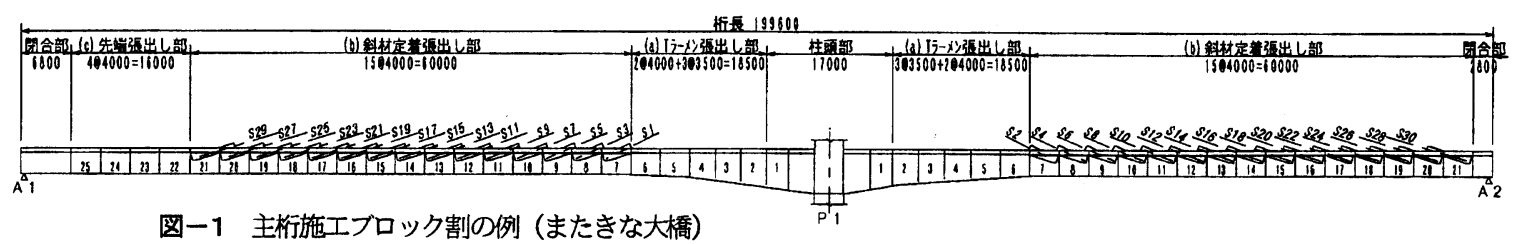

図ー1 主桁施エブロック割の例（またきな大橋）

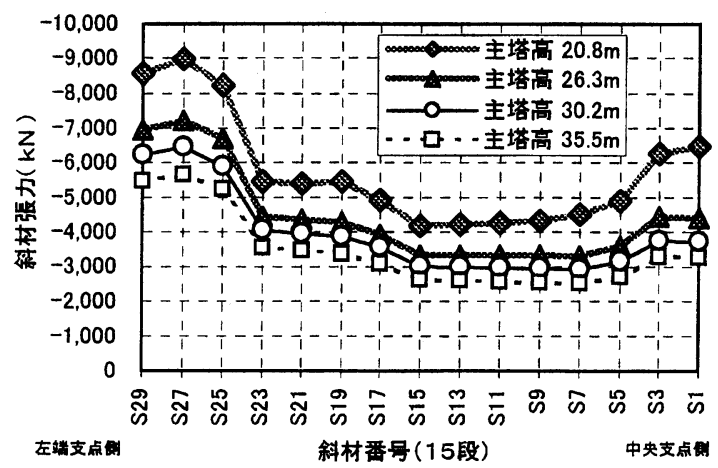

图一2 主塔高変化と斜材張力（設計荷重時）

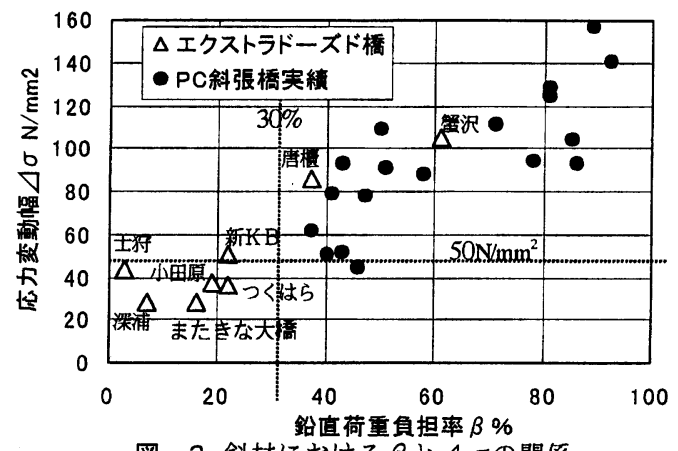

図ー3 斜材における $\beta$ と $\Delta \sigma$ 関係

\section{c) 主塔高と斜材張力（斜材径）}

主塔高を高くした場合，図一2のように斜材張力が減 るため斜材径を減らすことができる．斜材の規格も主塔 高 $22 \mathrm{~m}$ 時に SWPR22S15.2 ( $\phi 15.2 \mathrm{~mm}$ 鋼より線 22 本の 束）が主塔高 $36.7 \mathrm{~m}$ 時には $12 S 15.2$ (同じく 12 本の束) と半分近くまで減らすことができる. $\$ 25,27,29$ の 3 段は 斜材で端部張出し部荷重を負担するため高い.

\section{d) 斜材の許容灾力度}

斜材の許容応力度は, エクストラドーズド橋の $0.6 \mathrm{Pu}$ (Pu : 斜材引張強度) に対して, 斜張橋は $0.4 \mathrm{P}_{\mathrm{u}}$ であり, 2 径間高塔型の斜材許容応力の採り方が問題となる. 現 在有力なエクストラドーズド橋区分として，既往実績に よる「斜材の鉛直荷重負担率 $\beta$ か $30 \%$ 以下」と斜材の疲 労安全性による「活荷重に対する斜材応力変動幅 $\Delta \sigma か ゙$ $50 \mathrm{~N} / \mathrm{mm}^{2}\left(5 \mathrm{kgl} / \mathrm{mm}^{2}\right)$ 以下」の2 提案がなされている ${ }^{1)}$.

なお, $\beta$ は斜材への張力と設置角度によって算定され， 「主塔が高い, 斜材張力が大きい, 主析剛性が小さい」

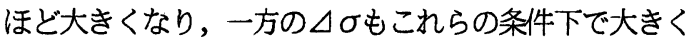
なることから両值は概ね比例関係にある.

2 径間高塔型のまたきな大橋の場合, 表一 $1,2 の \Delta \sigma$

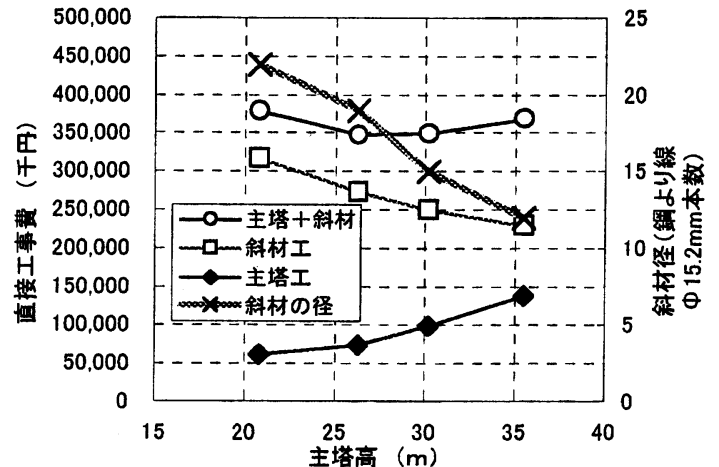

図-4 主塔高と工事費関係（蚛縄割增し含み）

および図一3の $\Delta \sigma, \beta$ はともに十分低く，斜材許容応 力度 $0.6 \mathrm{Pu}$ の使用は問題ないと判断できる.

\section{（4）主塔高增と主桁高隇の限界}

各部材とも限界があり，斜張橋寸法までは至らない。

(1) 主塔高：主塔高增も限度を過ぎると張力低減効果は 減退し主塔工費は高騰し経済性が低下する，維持補修 を含むトータルコスト上も適当な主塔高が好ましい。

(2) 主桁高：斜張橋よりも格段に大きな曲げモーメント に耐えるために, より大きな主桁高を必要とする.

(3) 斜材応力変動幅 $\Delta \sigma$ : 主塔高増または主桁高減に従 って $\Delta \sigma$ は増大するが, $50 \mathrm{~N} / \mathrm{mm}^{2}$ 以下に制約される.

(4) 斜材張力 : 主塔高増または主桁高減によって斜材張 力が相対的に増せば，架設時のオーバープレストレス が起きやすくなり，張力を有効に活かせなくなる.

\section{（5）主塔高変化の経斉的評価}

主塔高と費用（主塔工と斜材工の直接工事費）の関係 について図ー4に示す．費用は実施工值を参考に概算し たもので，主桁高と桁内 $\mathrm{PC}$ 鋼材モ一メントは変わらな いため主桁工費用は同一と考えられ，主塔工と斜材工の 合計費用によって経済的な主塔高を確認した。

(1) 主塔工： 主塔高を高くするに従い斜張橋特有の「高 軸圧縮力を受けるスレンダーな部材の地震時挙動」に 対して, 軸方向鉄筋の堌分, 主塔横梁の設置等が必要 となり，主塔高増に伴ってより費用高となる。

(2) 斜材工： 斜材工費用は設置工事も含めて斜材重量 に大きく支配されるため, 主塔高増に伴い斜材径が直 線的に減れば，斜材工費は直線的に隇る。

(3) 主塔工十斜材工：当条件では主塔高 $25 \sim 30 \mathrm{~m}$ か経 済的に優れる. 


\section{4. 最適主塔高の検佂}

前述のように主塔高増による経滓刘果は大きいが, 当章では桁内 $\mathrm{PC}$ 鋼材比率を従来なみに高くして斜材 段数を抑えたモデルで解析を行って, 主塔高増効果を 検証した.解析は, 图一5のモデルで行い, 主塔高 (橋 面から主塔先端まで）を $21.5 \mathrm{~m}, 26.5 \mathrm{~m}, 31.5 \mathrm{~m}$ と変え て桁内 PC 鋼材量 (内ケーブル)への影響を算定した。

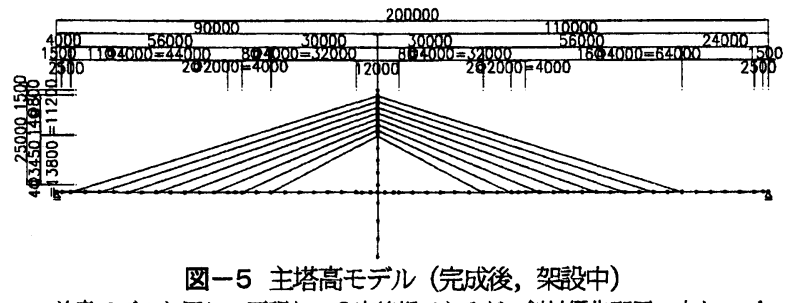

前章モデルと同じ 2 面張り， 2 室箱桁であるが, 斜材優先配置 $\rightarrow$ 内ケーブ 儿併用, 等径間 $\rightarrow$ 非対称径間, 斜材数 15 段 $\rightarrow 8$ 段, 主枌高 (柱頭部 標軯 部) $6 \mathrm{~m} \sim 3.5 \mathrm{~m} \rightarrow 5 \mathrm{~m} \sim 3 \mathrm{~m}, \mathrm{~B}$ 活荷重 $\rightarrow \mathrm{A}$ 活荷重のように条件を見直した.

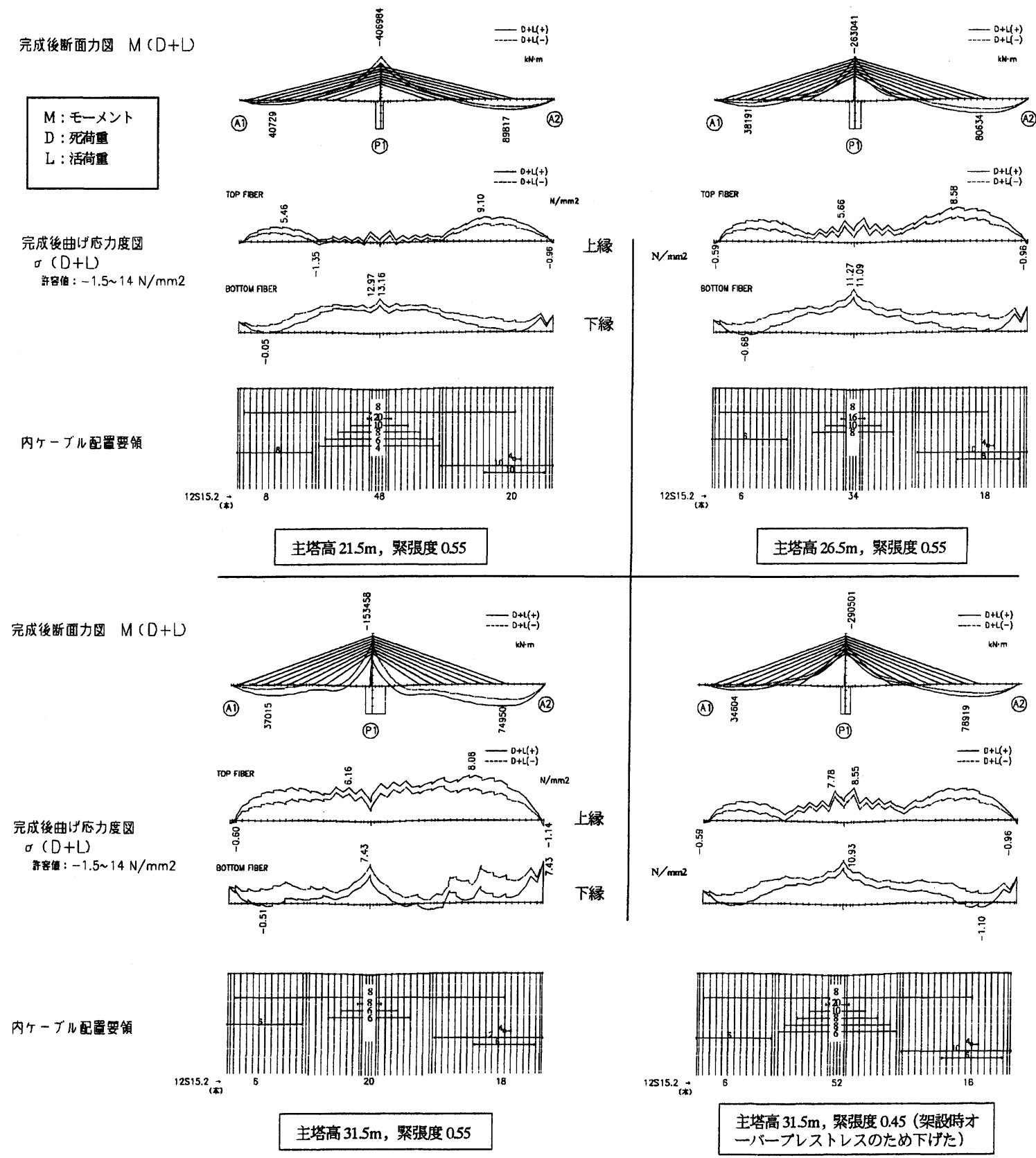

图-6 主塔高变化の曲げモーメント・上下縁応力度・内ケーフル本数への影翌 


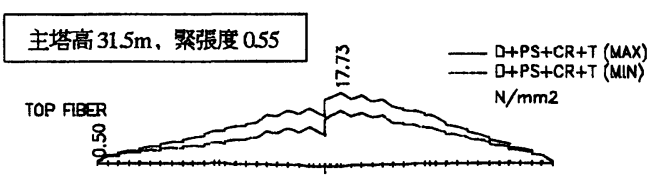

BOTTOM FIBER

(4)

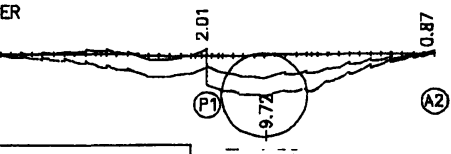

主塔高 $31.5 \mathrm{~m}$, 祭張度 0.45
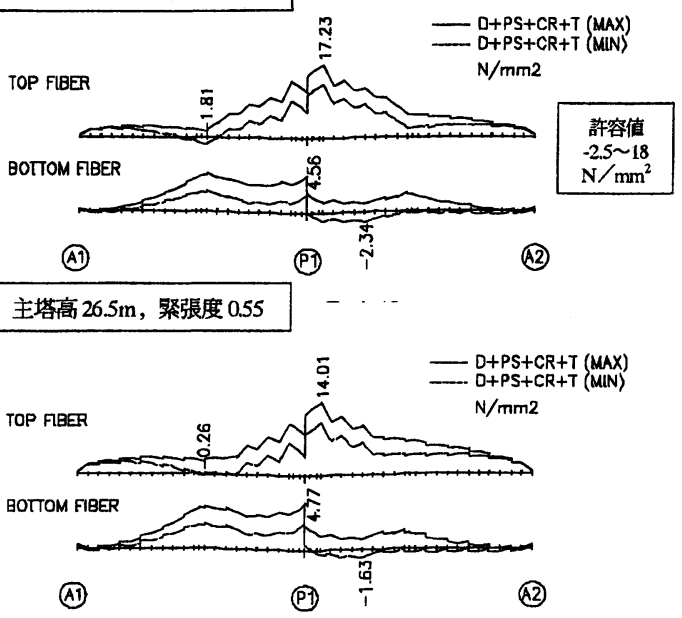

図ー7 架設中の曲げ応力図（主塔高 $31.5 \mathrm{~m} ， 26.5 \mathrm{~m}$ )

\section{(1) 曲げモーメント}

主塔高 $21.5 \mathrm{~m}$ から $26.5 \mathrm{~m}$ に変化した場合, 柱頭部の負 モ一メントは約 $144,000 \mathrm{kN} \cdot \mathrm{m}$ 減じられ, その効果は大き い. 同様に, 支間中央付近の正の曲げモーメントも減じ られるが, 主塔高 $21.5 \mathrm{~m}$ と $26.5 \mathrm{~m}$ の差は $9,200 \mathrm{kN} \cdot \mathrm{m}$ 程度 とやはり大きい.（図一6の各ケース上段）

\section{（2）主桁に発生する上縁下縁の曲け蝶力}

道路橋示方書では主桁部コンクリートの許容値として

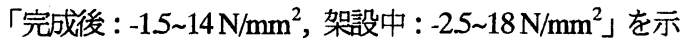
しており，これを満足するように内ケーブル（12S15.2） 本数の加減を行った. (図一6の各ケース中・下段)

\section{a) 完成後}

主塔高増に伴って柱頭部負の曲げモーメントは低減し， これによって主桁上縁引張応力と下縁圧縮応力は大きく 滅じられ, 上縁引張応力減は桁内 $\mathrm{PC}$ 鋼材 (内ケーブル) の減, 下緑王縮応力は主桁高隇につながる.

主塔高ごとに見ると， $21.5 \mathrm{~m}$ で既に柱頭部周辺の上縁 引張応力はほぼ無くなっており, 同時に斜材の無い左端 支間近くにあった下縁引張応力も圧縮側に転じている。 主塔高 $26.5,31.5 \mathrm{~m}$ と高くなると柱頭部周辺は $5 \sim 8 \mathrm{~N} / \mathrm{mm}^{2}$ の圧縮応力に転じている. 応力バランス的には，斜材に よるプレストレスが適度に効き許容值との余裕も適度に ある主塔高 $26.5 \mathrm{~m}$ が優れている.
表一3 主塔高と斜材の鉛直荷重分担・応力変動幅

\begin{tabular}{|c|r|r|r|}
\hline 主塔高 $\mathrm{H}$ & \multicolumn{1}{|c|}{$21.5 \mathrm{~m}$} & \multicolumn{1}{c|}{$26.5 \mathrm{~m}$} & \multicolumn{1}{|c|}{$31.5 \mathrm{~m}$} \\
\hline 鉛直荷重分担率 $\beta \%$ & 6.8 & 10.3 & 13.8 \\
\hline 応力変動幅 $\Delta \sigma \mathrm{N} / \mathrm{mm}^{2}$ & 27 & 33 & 37 \\
\hline
\end{tabular}

主塔高モデル (完成後), 主晰·斜材は同一条件, HB1.5m は緊張度 0.45 Mux

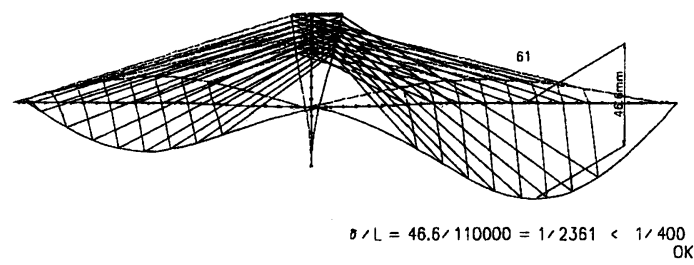

図ー8 活荷重によるたわみ状況（主塔高 26.5m）

\section{b) 架設中（最大張出し時）}

完成後と同様に，主塔高増に伴って柱頭部負の曲げモ 一メントは低減し応力状態は改善されるが，主塔高 $30 \mathrm{~m}$ の場合は，斜材プレストレスが効きすぎて柱頭から長支 間中央部にかけて下縁部に $9.72 \mathrm{~N} / \mathrm{mm}^{2}$ の許容值を超える 引張応力が生じ, 同時に上緑王縮応力も許容值にほぼ達 する.このような過大な応力状態 (以下，オーバープレ ストレス）を解消するために，図一フでは，斜材の緊張 度を 0.55 から 0.45 まで下げて対応した。

緊張度は, $0.6 \mathrm{P}_{\mathrm{u}}\left(\mathrm{P}_{\mathrm{u}}\right.$ : 引張強度) が許容值だが, 施工 上はばらつきを考虑して $0.55 \mathrm{P}_{\mathrm{u}}$ 程度が上限である。

\section{（3） 斜材の鉛直荷重分担率と活荷重応力変動幅}

表一3のように主塔高増に従って斜材の鉛直荷重分担 率 $\beta$ 值は増すが，エクストラドーズド橋区分提案の $30 \%$ まではかなり余裕がある.

斜材の活荷重応力変動幅 $\Delta \sigma$ は, 鉛直荷重分担力が多 いほど大きくなる．表一3では，各值は疲労安全目標度 の $50 \mathrm{~N} / \mathrm{mm}^{2}$ までかなり余裕をもって収まっている.

2 径間の場合は両端支点が支持されるので，斜材への 応力負担は軽減され， $\beta, \Delta \sigma$ ともに低い值となる.

\section{（4）活荷重による主妳のたわみ}

図一8に示すように，2径間の特性でたわみ量は十分 に小さく，たわみ変形に対して優れている. ちなみに， 最大たわみ量の支間に対する比は 1/2361 で, 道路橋示方 書鋼橋編の許容值 $1 / 400$ と比較しても余裕がある.

\section{（5）オーパープレストレス状態}

解析上主塔高増に伴い，架設時にオーバープレストレ スが起きたが，この解消のため斜材張力を弱めても完成 形で桁内 P C 鋼材の大幅追加が必要であり，オーバーフ レストレスは経済上の限界を意味する.オーバープレス トレスは主析剛性に対して斜材張力が相対的に強い場合 に生じるため，主桁高を低くした場合は要注意となる。 
表一4 概算数量の比較

\begin{tabular}{|c|r|r|r|r|r|}
\hline \multirow{2}{*}{ 項 目 } & & \multicolumn{3}{|c|}{ 主塔高 } & 不採用 \\
\cline { 3 - 6 } & & $21.5 \mathrm{~m}$ & $26.5 \mathrm{~m}$ & $31.5 \mathrm{~m}$ & $31.5 \mathrm{~m}$ \\
\hline 斜材ケーブル & ton & 40.6 & 41.7 & 43.1 & 43.1 \\
\hline & ton & 47.5 & 29.5 & 42.5 & 17.4 \\
内ケーブル & 本 & 48 本 & 34 本 & 52 本 & 20 本 \\
\hline 主塔躯体量 & $\mathrm{m}^{3}$ & 276 & 346 & 416 & 416 \\
\hline 上記計コスト比 & & 1.10 & 1.00 & 1.20 & 0.97 \\
\hline
\end{tabular}

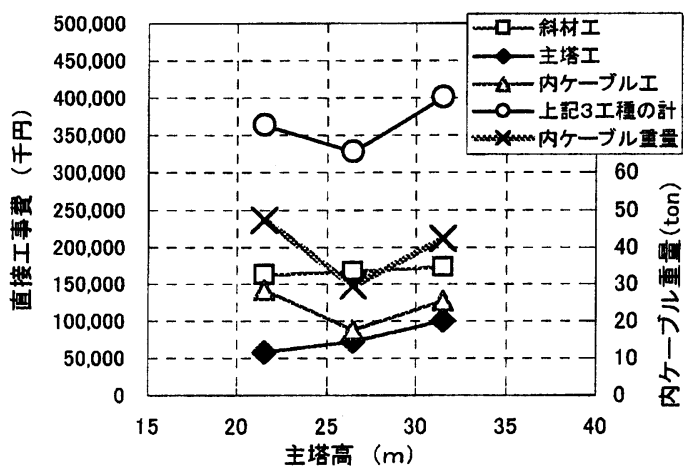

図-9 主塔高と斜材、主塔工事費（蝿割增し含み）

なお, 斜張橋では, 斜材張力が弓張強度の 4 割以下と より低いとともに頻繁な張力調整を行うことによって架 設中のオーバープレストレスを解消している.

\section{（6）主塔高増の主桁内PC鋼材量への影暗}

表ー4に桁内のプレストレスト用として配置すべき内 ケーブル (12S15.2: $\phi 15.2 \mathrm{~mm}$ 鋼より線 12 本の束) の本 数（連続用を除く）を示すが, 最も集中する柱頭部にお いて主塔高 $21.5 \mathrm{~m}$ で 48 本, $26.5 \mathrm{~m}$ で 34 本, $31.5 \mathrm{~m}$ で 20 本（緊張度 $0.55 ）$ と主塔が高くなるにつれて斜材の鉛直 荷重分担効果が高まり,必要内ケーブル本数は減少する.

ただし, 主塔高 $31.5 \mathrm{~m}$ では架設中オーバープレストレ ス解消のため斜材張力を下げたことから, 斜材の大偏心 プレストレスが減少し内ケーブルは 52 本に激増する.

\section{（7）経済性比較（図一9）}

主塔高 25〜30m か経済的な範囲と考えられるが, 主塔 高が $31.5 \mathrm{~m}$ に達するとオーバーブレストレスを避け斜材 張力を下げる必要が生じることから内ケーブルが増え， 主塔部の材量增も加わりコスト高となる. 一方, 主塔高 $21.5 \mathrm{~m}$ では柱頭部の負の曲げモーメントが大きいため, その分の内ケーブル費の増が主塔の部材量減と斜材延長 の減よりも大きいことで経済性は悪化する.

\section{（8） 解析モテルの䢖いの評価}

当章のモデルは 3 章と比較して, 斜材の配置方法, 径 間対称性, 斜材段数, 活荷重条件等で違いはあるが, 3 , 4 章の異なる 2 モデルにおいて同様の「主塔高 $25 \mathrm{~m}$ $30 \mathrm{~m}$ が経済的に優れ, 力学的罗当性も有する」という結
果を得た.このことで，2径間かつ側径間長 $110 \mathrm{~m}$ 規模 の条件ながら「主塔高はある程度高い方か経済的に有利 である」と判断できる. ただし, 主塔高増は上限を有し 「経済性（主塔高増が割高の主塔構造補強にならない）, 力学的合理性 (斜材の応力変動幅と鉛直荷重負担率力゙斜 張橋区分に入らない, オーバープレストレスの回避), 維 持補修性 (今回は高所作業車の作業限界に考慮した)」を 満たす高さによって決定すべきであると考える.

\section{（9）2 径間高塔型数棓十の効率的進め方}

今回の 2 径間高塔型エクストラドーズド橋における最 適設計の進め方を各部材特性に基づいて以下に整理する。 (1) 斜材の架設区間と段数をまず設定し, 必要な主桁高 を片持ち梁計算により算定する.

(2) 完成後モデルと架設中（最大張出し時）で主塔高を 数ケース変化させて主桁内の応力度を確認する.

(3) 力学的かつ経済的に上限の主塔高を設定する.

(4) 張力状態を確認して斜材の径と段数を最適化する.

(5) 斜材応力変動幅について $50 \mathrm{~N} / \mathrm{mm}^{2}$ 以下を確認する.

\section{2径間高塔型エクストラドースド橋の適用}

\section{（1）維持補修性を考虑した主塔高}

維持補修上は県内最大級の高所作業車の作業限界 $25 \mathrm{~m}$ 以内が望ましい, 最上段斜材が橋面より $25 \mathrm{~m}$ に配置され る最終主塔高 $26.4 \mathrm{~m}$ はこれを満足するものである.

\section{（2）斜材段数の增}

実施工においては下記の施工の円滑化を目指して斜材 優先配置を採用した. その結果, 斜材段数は 15 段と多め となったが, 桁内 PC 鋼材量は大きく低減され, 斜材段 数増による設置工費増と相殺された.

(1) 張出しブロック長の $4 \mathrm{~m}$ 間隔で斜材を緊張できるた め主桁工がルーチンワーク化し, 工程短縮につながる.

(2) 桁内ケーブルを減らすことで主桁工が簡略化する. 斜材設置工は増えるが, 主桁工との並行作業が可能.

(3) 斜材径が小型化して取扱いが容易となる.

(4) きめ細かく発生応力に対応できることで，施工中お よび完成後の安全性が増す。

\section{（3）施工性を考虑した主桁高}

主桁高（柱頭部〜標準部） 6 -3m は発生応力が僅かに 許容值を超えるため実施工では 6 3.5m を採用したが， 主桁岡性に余裕を持たせたことで，「施工上手間となる 主桁高の変化区間（柱頭部から標华部へのすりつけ部） の短縮, より大型の張出し用ワーゲンを用いての施工合 理化」を行うことが可能となった. 


\section{（4）斜材張力と径}

斜材張力は斜材架設区間の関係から最外側が大きな張 力を必要とし, 当橋梁では, 斜材 15 段のうち最外側の 3 段は太目の $27 \mathrm{~S} 15.2$ ( $\phi 15.2 \mathrm{~mm}$ 鋼より線 27 本の束) を 使用し，他の段は標準的な 19S15.2 を用いた. 12S, 19S， $27 \mathrm{~S}$ が汎用規格品であることから，「張力に応じて斜材 の径を変え，汎用規格品の径に収めることで経済性が相 当に増す」と言える. 図一-10に 15 段 2 面の各斜材にお ける緊張度分布を示すが，長短径間とも最外側を高く内 側に行くほど徐々に下げ，最内側で再び高めている。

\section{(5) 斜材応力変動}

斜材の活荷重応力変動幅 $\Delta \sigma$ を図ー10に示す. 安全目 標值の $50 \mathrm{~N} / \mathrm{mm}^{2}$ 以下を全ての值が余裕をもって満足し ており, 当橋梁の優れた疲労耐久性を示している.

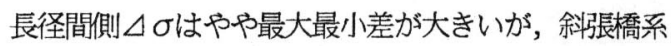
の標準的傾向を示す，一方，短径間側は長径間のたわみ

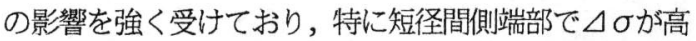
いのは近接する端支点に拘束されるため張力最小時に圧 縮側に転じて最大最小時の幅が増大するためである.

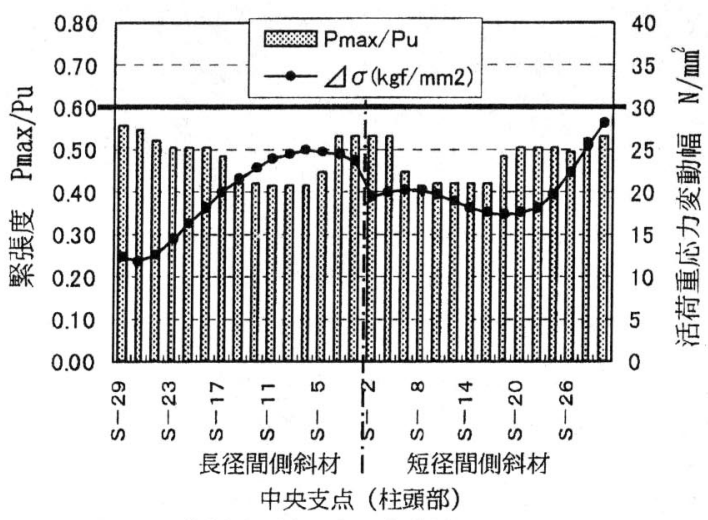

図-10 斜材緊張度・応力变動幅 (実施工モデル設計荷重時)

\section{（6）実施工モデルでの応力状况}

実施工構造の曲げモーメント，応力度状況を図一11 に示す. 柱頭部は-200,000kN·m と主椼断面で対応可能な 曲げモーメント值に適度に抑えられ,特徵として,「下縁 は $10 \mathrm{~N} / \mathrm{mm}^{2}$ を超えて無䭾が少ない，応力度は圧縮側に 効率的に平滑化されている. 斜材が 15 段と多いため, 応 力上の凹凸がより少なくなっている.」等がある.
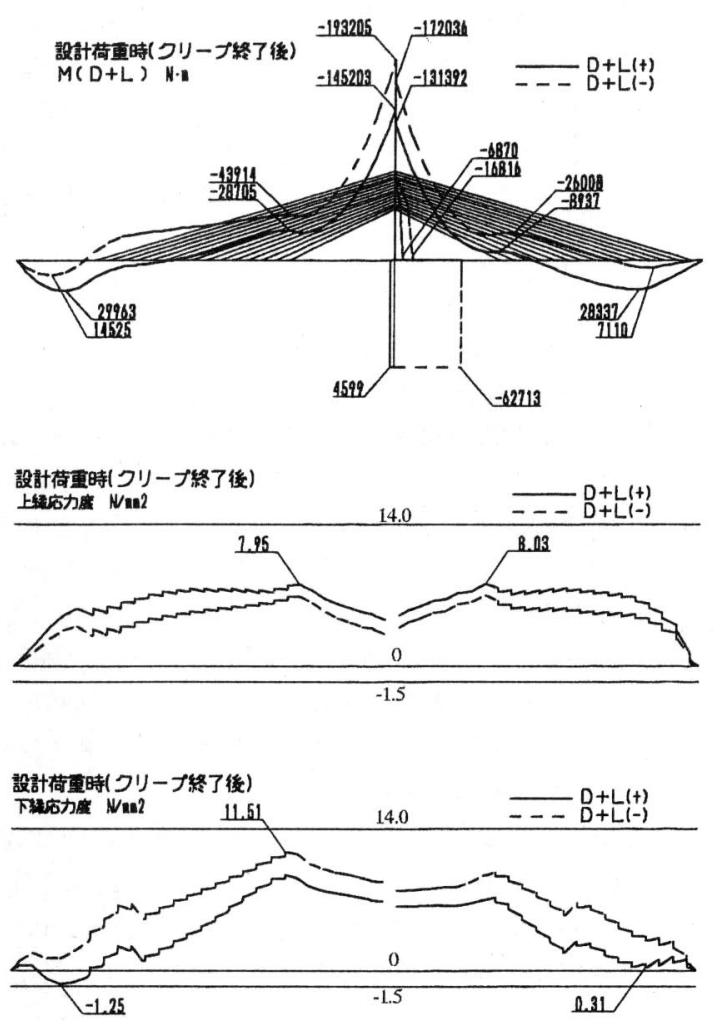

図ー11 曲げモーメント・応力度図（実施工モデル） 設計荷重時 (死荷重 $+\mathrm{A}$ 活荷重)，クリーフ乾燥収縮釉了後

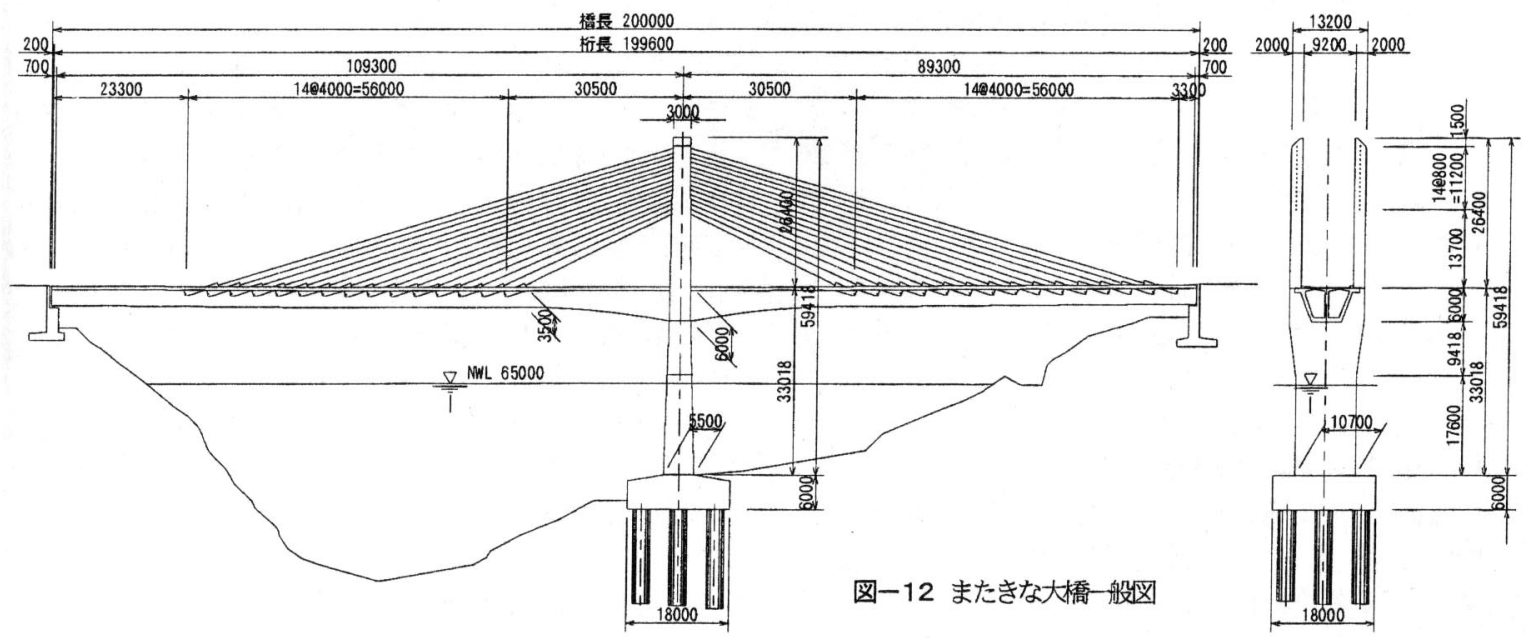


表一5 主要工事数量

\begin{tabular}{|c|c|c|c|c|}
\hline 項 & 目 & $\begin{array}{l}\text { エクストラト } \\
\text { ースド橋 (1) }\end{array}$ & $\begin{array}{l}\mathrm{PC} \text { 斜 張 } \\
\text { 橋(2) }\end{array}$ & $\begin{array}{l}\text { 数量差 } \\
\text { (1)-(2) }\end{array}$ \\
\hline \multicolumn{2}{|l|}{ 主塔高 } & $26.4 \mathrm{~m}$ & $47 \mathrm{~m}$ & $-20.6 \mathrm{~m}$ \\
\hline \multicolumn{2}{|l|}{ 主桁高 } & $3.5 \mathrm{~m}$ & $2.0 \mathrm{~m}$ & $1.5 \mathrm{~m}$ \\
\hline \multirow{3}{*}{$\begin{array}{l}コ ン ク ~ \\
\text { リート }\end{array}$} & 主桁 & $2,559 \mathrm{~m}^{3}$ & 1,700 & \multirow{3}{*}{$-326 m^{3}$} \\
\hline & 主塔 & $319 \mathrm{~m}^{3}$ & 780 & \\
\hline & 下部 & $3,376 \mathrm{~m}^{3}$ & 4,100 & \\
\hline \multirow{3}{*}{ 鉄筋 } & 主桁 & 339.7 ton & 320 & \multirow{3}{*}{-76.9 ton } \\
\hline & 主塔 & 53.1 ton & 120 & \\
\hline & 下部 & 370.3 ton & 400 & \\
\hline \multirow{3}{*}{ 型枠 } & 主桁 & $8,090 \mathrm{~m}^{2}$ & 6,300 & \multirow{3}{*}{$830 \mathrm{~m}^{2}$} \\
\hline & 主塔 & $490 \mathrm{~m}^{2}$ & 1,100 & \\
\hline & 下部 & $1350 \mathrm{~m}^{2}$ & 1,700 & \\
\hline \multicolumn{2}{|c|}{ 桁内 P C 鋼材 } & *57.9 ton & 95 & -37.1 ton \\
\hline \multicolumn{2}{|c|}{ 斜材鋼材 } & 88.7 ton & 91 & -2.3 ton \\
\hline
\end{tabular}

$* \mathrm{P} \mathrm{C}$ 鋼棒 $\varnothing 32 \mathrm{~mm}$ を用いた。

\section{（7）合理化施工導入による工期短縮}

斜材と主桁に関する上記対応によって，7ブロック以 降の箱桁の断面形状を同一とし，張出しに関する作業を 単純化したことにより,「ウェブ鉄筋のプレハブ化と， ンセパ型枠システム」の合理化施工採用が可能となった。 その結果, 張出し工の施エサイクル（打設〜脱型〜ワ 一ゲン移動〜鉄筋組立て〜打設)は 14 日から 8 日へ大幅 に短縮された. また，斜材架設開始から張出し工完了ま でが台風時休止も含む5 ケ月半(平成 11 年 7 月初旬から 12 月中旬まで）で達成され, 当初予定の 11 ケ月と比較 して工期は大幅に短縮された。

実施工で，全体に剛性か増す方向（主桁高の増と斜材 段数の増)で構造諸元を修正したが，「合理化施工を採用 しやすいように部材諸元を修正することでトータルコス 卜上有利となる」と考えられる.

\section{（8）施工数量と経済性}

元設計の PC 斜張憍と今回エクストラドーズド橋の主 要工事数量を実施設計レベルで比較した結果を表一5に 示すが，金額的に最も多い主桁躯体量の増を抑えたこと で，全体数量としても低隇することが可能となった.

コスト縮減は「主塔高の半減, 斜材定着装置の汎用品 化, 張力調整の不要化, 桁内 PC 鋼材の減」等の効果が 大きい，また，桁断面が大きくなったことによる部材量 の増は生じたが，主桁岡性が増した分，主桁内 $\mathrm{P} C$ 鋼材

(特に鉛直締め, 横締め) は減った. 以上によって, 橋 梁工事費の約 $20 \%$ 節減された. さらに, 総合的な経済 性は工期短縮によってさらに向上したと評価できる.

\section{（9）施工中計測による設計の確認}

計測は, 主に施工中の躯体の応力状態および上越し管 理のバックデータとなる施工管理計測と，斜材の振動を 計測する風応答観測を行った. (1)〜6項目)

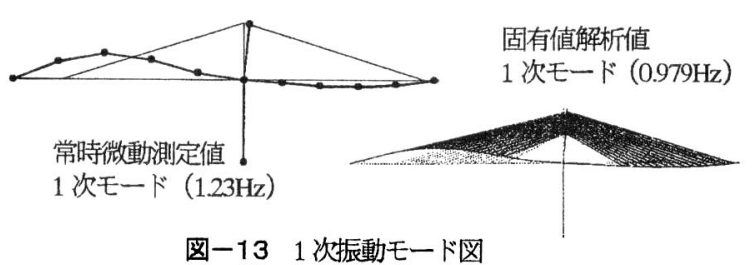

表-6 振動数と減衰定数の実績值比較

\begin{tabular}{|c||c|c|c|}
\hline 橋梁名称 & 径間長 $[\mathrm{m}]$ & 振動数 $[\mathrm{Hz}]$ & 滅衰定数 \\
\hline 2径間斜張橋 $\mathrm{A}$ & $126.5+126.5$ & 0.496 & 0.0066 \\
\hline /I B B & $113.4+113.4$ & 0.558 & 0.0062 \\
\hline II C & $94.3+94.3$ & 0.740 & 0.0150 \\
\hline /I D & $84.4+84.4$ & 0.910 & 0.0110 \\
\hline II E & $53.5+53.5$ & 1.022 & 0.0120 \\
\hline /I F & $37.45+37.45$ & 1.600 & 0.0161 \\
\hline またさな大橋 & $110+90$ & 1.230 & 0.0120 \\
\hline
\end{tabular}

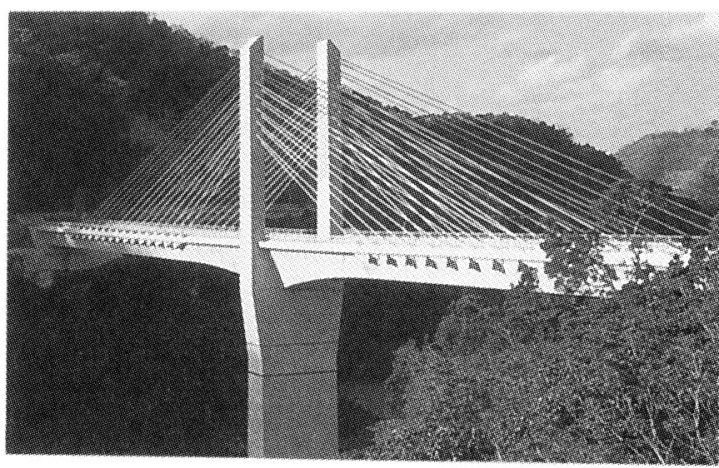

写真ー1 またきな大橋全景（右岸上流側から）

その結果, 斜材張力, コンクリート応力, 傾斜等とも に異常なく設計值の範囲内にあることを確認した.

(1) 斜材張力 (緊張時導入力・張力経時变化)

(2) 主桁橋面標高（施エステップ毎）

(3) コンクリート応力度 (主桁・主塔)

(4) 傾斜（柱頭部高さ・主塔中間高さ）

(5) 温度 (主析・ダミ一斜材・気温)

(6) 斜材グラウトが終了後の風による斜材の振動

\section{（10）現地振動実験による構造罗当性の確認}

長大径間かつ左右非対称である当橋梁の振動特性の把 握と耐震設計の妥当性の検証を目的として，常時微動に よる振動モードの同定とトラック衝撃加振実験による減 衰定数の測定を実施し, 構造妥当性を以下確認した.

(1) 常時微動測定から得た 1 次モード振動数 $1.23 \mathrm{~Hz}$ は固 有值解析モデルの值に近く, 解析モデルは妥当である.

(2) トラック加振実験による減衰定数は 0.0120 であった.

(3) 2 径間P C 斜張橋のみを選び出し, 面内逆対称 1 次 モードの振動数と減衰定数の比較を行った結果, 当橋 梁の振動数と減衰定数は径間長が長いにもかかわらず 高目であり, 2 径間高塔型は 2 径間斜張橋よりも剛性 が高いことを確認した.(表ー6) 
表ー7 2径間高塔型の長径間化モデルの諸元

\begin{tabular}{|c|c|c|c|c|}
\hline 橋 長 & 主塔高 & 主析高 & 斜材段数 & 斜材架設位置 \\
\hline $110 \mathrm{~m} \times 2$ & $26.3 \mathrm{~m}$ & $6.0 \sim 3.5 \mathrm{~m}$ & 15 段 & $\begin{array}{c}\text { 中間支点より } \\
30.5 \sim 86.5 \mathrm{~m}\end{array}$ \\
\hline $130 \mathrm{~m} \times 2$ & $31.3 \mathrm{~m}$ & $6.5 \sim 4.0 \mathrm{~m}$ & 18 段 & $36.5 \sim 104.5 \mathrm{~m}$ \\
\hline $150 \mathrm{~m} \times 2$ & $36.3 \mathrm{~m}$ & $7.0 \sim 4.5 \mathrm{~m}$ & 20 段 & $44.5 \sim 120.5 \mathrm{~m}$ \\
\hline
\end{tabular}

斜材径は SWPR19S15.2 を採用，斜材緊張度 0.55Pu，B活荷重， クリーフ乾燥収縮後, ファン形 2 面張り, 応力許容值-1.5〜 14N/mm 2

\section{2径間高塔型における長径間化の検討}

2 径間高塔型エクストラドーズド橋の優れた構造特性 を活かしての長径間化を試みた。限界まで長径間化する ことで，2径間高塔型の特性がより明らかになった。

\section{（1）長径間化モテルの諸元設定}

またきな大橋をべースとした 2 径間高塔型対称形のエ クストラドーズド橋を径間 $110,130,150 \mathrm{~m}$ と長大化した.

各径間長とも, 完成後と架設中の主标上下縁応力度が 許容值内に入り, 斜材応力変動幅も安全目標值である $50 \mathrm{~N} / \mathrm{mm}^{2}$ 以下になるように数回試算して構造諸元の最適 化を行い表ー7のような2 径間高塔型モデルとした。

\section{(2) 主桁断面力およひ応力度}

表ー7モデルにおける主桁内の断面力および発生応力 の状況を下記のように取りまとめた.

a) 曲げモーメント

長径間化するに従い主桁自重か増すため, 斜材張力を 強くして柱頭部の負の曲げモーメントビークを低くして も主析応力を許容值内に収めるのが難しくなる。

図ー14の径間 $150 \mathrm{~m}$ のモーメント図は柱頭部のモーメ ントピークが適度に低減されており，斜材張力設定が適 正であることを示している.これ以上，斜材張力を与え モーメントピークを低くした場合は，主桁の過大㐫力と 架設中オーバープレストレスの問題が生じた。

\section{b) 軸力}

斜材によって橋軸方向の力は中央に引き寄せられるた め軸力の最大值は常に柱頭部に生じるが，これは主桁へ のプレストレスカでもあり，主析に発生する引張応力の 低減に大いに役立つ.長径間モデルでの軸力は径間 $110 \mathrm{~m}$ で $105,900 \mathrm{kN}, 130 \mathrm{~m}$ で $129,600 \mathrm{kN}, 150 \mathrm{~m}$ で $147,600 \mathrm{kN}$ と長径間化による斜材增につれて増加する. (図一14)

\section{c) 上下緑応力度}

長径間化するに従い上縁応力が圧縮側に増し，径間 $150 \mathrm{~m}$ では上縁応力が下縁応力と最大值で同じとなり， 上縁下縁応力ともに最大值は許容值 $14 \mathrm{~N} / \mathrm{mm}^{2}$ 近くまで 達しており，応力上の限界状態にあることを意味する.

さらに長径間化を図る場合, 斜材張力増は上縁王縮応 力を増やすため逆効果であり，主桁高增も死荷重力增え るため斜材張力増につながり効果はない（図ー15)
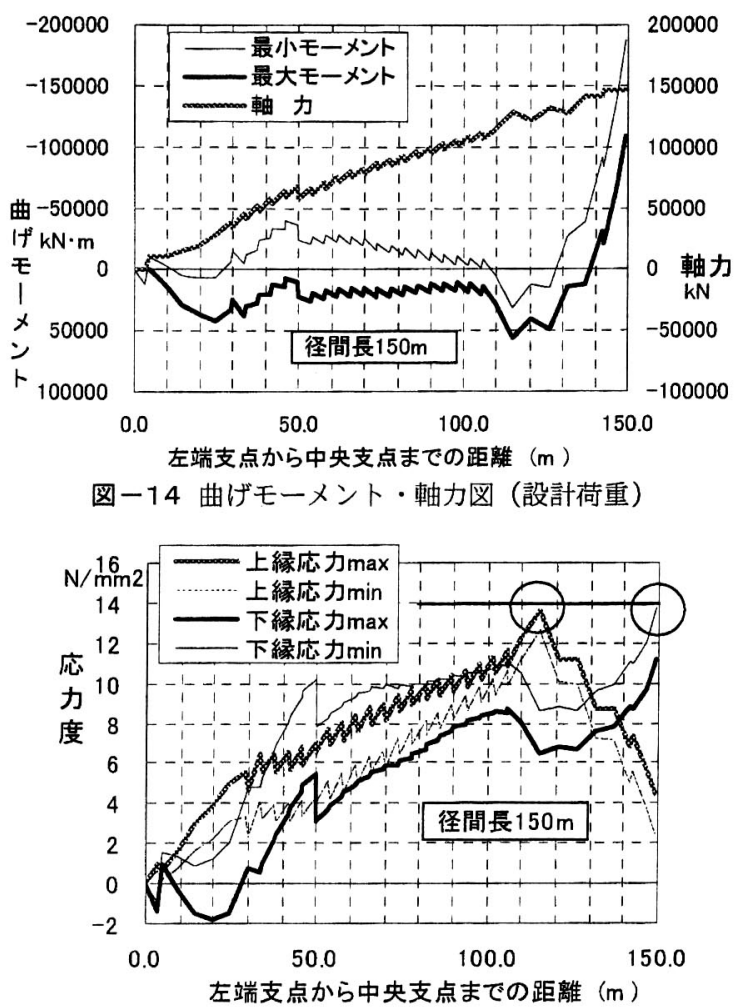

図-15 主桁発生応力図（設計荷重）

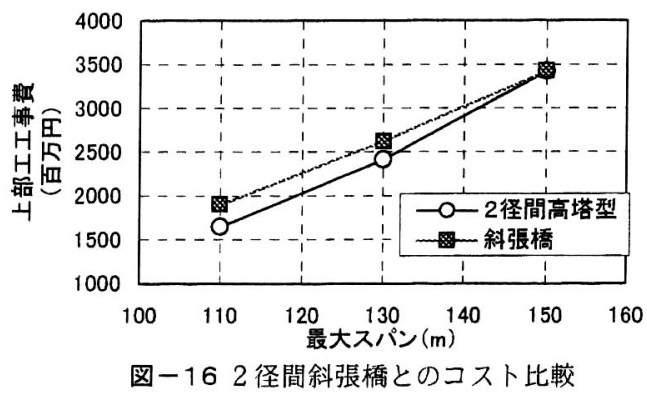

\section{（3）長径間化の方策}

主桁応力状態から径間長 $150 \mathrm{~m}$ が，今回の 2 径間高塔 型エクストラドーズド橋モデルの力学的上限に近いと考 えられる. 更なる長径間化のためには，主塔をさらに高 くした上で「柱頭部側に斜材を加えて主标圧縮応力度を 分散する，標準部主桁高を減じて軽量化を図る，柱頭部 主桁高を増して主桁圧縮応力度に対応する」等が有効と 考えられるが，一段と斜張橋化することである. なお， 鋼桁との複合構造による長径間化は実際に行われている.

\section{（4）長径間化の経済上の上限}

2 径間高塔型エクストラドーズド橋（概算）と 2 径間 斜張橋（実績推定）との経済比較を行ったところ，径間 長 $150 \mathrm{~m}$ で両者は同等となった．よって，経済的にも径 間長 $150 \mathrm{~m}$ 程度が当形式の上限と考えられる. (図-16) 


\section{7. 結 論}

既往最大級の張出し長 $110 \mathrm{~m}$ を対象とした 2 径間エク ストラドーズド橋において, 主塔を高くすることの力学 的かつ経済的な利点を解析によって理論化し, 設計〜施 工を通じて妥当性を確認した. 以下に結論をまとめる.

\section{a) 主塔高}

主塔高の増に伴い斜材効果が高まるため主桁内の応力 は軽減され, 斜材または桁内 PC 鋼材の大幅な数量減が 可能となる.このことをパラメー夕解析によって示し, 主塔高増の経済効果が大きいことを明らかにした。

ただし,主塔高增は「構造補強による主塔工費の高騰, 架設時オーバープレストレスの発生, 斜材応力変動幅の 上昇, 維持補修費の高騰」等により上限を有する.

最適主塔高は, PC 鋼材の配分を斜張橋的な斜材優先配 置と桁内 $\mathrm{PC}$ 鋼材比率の高い従来型の 2 モデルで解析し た結果, 両方とも主塔高 $25 \mathrm{~m} \sim 30 \mathrm{~m}$ が力学的かつ経済的 に優れた範囲であった. よって, 主塔高増の効果につい て，ある程度の一般性を示すことができた。

\section{b) 主桁高}

主桁高（標潐部）の增により主桁剛性が増しても，自 重増により必要斜材張力も増えるために必ずしも経済的 とならないことをバラメー夕解析によって示した. ただ し，張出しに必要かつ斜材による軸圧縮力に耐え得る最 低限の主析高の確保は必要である。

\section{c) 斜材}

斜材特性を示す鉛直荷重分担率, 応力変動幅の両值と も従来エクストラドーズド橋と比べて十分低く，2 径間 高塔型が許容応力度 $0.6 \mathrm{Pu}$ を採用できることを示した.

斜材段数は, 総 PC 鋼材量ミニマムの観点から斜材優 先配置としたため従来よりも多めの段数となったが, 段 数增によって施工性 (工程短縮) と安全性の向上に大き く寄与することを示した。 また，沉用規格の斜材径を探 用できるように椼内 PC 鋼材との配分および斜材段数を 決定することが経済性を大きく高めることを示した。

\section{d) 構造妥当性の確梕}

完成までの計測管理の結果, 応力状態, 而風性ともに 問題なく，2径間高塔型の力学的妥当性を実証した. ま た，現地振動実験によって剛性が高く，而震性には問題 ないことも確認した.

なお，経済的には本稿とは別に実施設計精度で元設計 の斜張橋と今回 2 径間高塔型との経済性比較を行い, 約 20\%の大きなコスト縮减率が得られたことを報告する.

\section{e) 長径間化および今後の可能性}

今回 2 径間高塔型構造では径間長 $150 \mathrm{~m}$ 程度が, 力学 上および経済上の上限值となることをモデル解析によう て示した. 長径間化には「主塔を高く, 主桁を軽く, 斜 材架設を広く」が重要である.

特に, 斜材の架設区間を広げることで「主桁高の隇に よる自重の減，等断面区間延長による施工合理化」等の 利点か增す. なお，架設中のオーバープレストレスにつ いては, 施工中の緊張力を低めにしておき完成時に 2 次 緊張を行うことで効率的に解決できる可能性もある.

謝 辞： 2 径間高塔型エクストラドーズト橋を適用した 「またきな大橋（沖縄県名護市）」は 2000 年 3 月に完成 し,その特徵ある姿は地域住民に大いに親しまれている. 計画時よりご指導頂いた横浜国大の池田尚治教授，本 稿にご指導頂いた鹿島建設土木設計本部, 鹿島・鉄建 $J$ $\mathrm{V}$ ，日本構造橋梁研究所の各位に謝意を表します。

\section{参考文献}

1）岡米男，春日昭夫，山崎凉: エクストラドーズト橋の構造特性に 関する一考察,プストレストコンクリート第39巻2号,1997.4.

2）小宮正久: エクストラドーズド橋P C 道路橋の設言十に関す る一考察, 土木学会論文集, 1995.6.

3）川崎秀明，山内明夫：またきな大橋における新しい設流坆工手 法, プレストレストコンクリート第42巻3号, 2000年6月.

(2000.5.1 受付)

\title{
STRUCTURAL CHARACTERISTICS ON TWO SPAN EXRADOSED BRIDGE WITH A HIGHER TOWER
}

\author{
Hideaki KAWASAKI and Hiromichi MATSUSHITA
}

\begin{abstract}
Exradosed bridges are recently increasing as a suitable bridge type between cable stayed bridges and box girder bridges, and the past tower height of exradosed bridges with three spans have been restricted under 10 to 15 meter. On the other hand, two span bridges supported by both ends have better precondition on stress fluctuation and displacement. It means that structural parts can be downsized with increasing tower heights. In this study, we analyzed characteristics of three main parts (tower, girder, cable) and tried to optimize a structural system. As a result, we found that the most suitable tower height is about $25 \sim 30$ meter, which is twice of the past examples. This result was confirmed through a construction, and shows a new approach to bridge structures.
\end{abstract}

